\title{
Succession Pattern of Insects in Relation to Killing Methods of Rattus norvegicus at Delta State University, Abraka, Nigeria
}

\author{
${ }^{1}$ OJIANWUNA, CC; ${ }^{* 1,2}$ ODIBO, OE; ${ }^{3}$ AKPAN, AU; ${ }^{1}$ EGWAOJE, KI \\ ${ }^{1}$ Department of Animal and Environmental Biology, Delta State University, Abraka, Nigeria. \\ ${ }^{2}$ Michael and Cecilia Ibru University, Agbarha-Otor, Delta State, Nigeria. \\ ${ }^{3}$ Entomology unit: Department of Animal and Environmental Biology, University of Uyo. Uyo. Akwa Ibom State. \\ *Corresponding author: E-mail: odibozinodollhouse@gmail.com; Tel: +2347039891274
}

\begin{abstract}
The succession pattern of insects associated with the strangling and slaughtering of rat (Rattus norvegicus) was conducted between March and June 2017. Four (4) Albino Wistar rats were killed using strangle and slaughter methods, one method for a pair. The rat carcasses were secured from scavengers and restricted from human interference in a way that did not necessarily restrict access to the carcasses and also enabled insect collection. Insects were collected daily by hand picking and with the aid of aerial net, forceps and fine paintbrush. Collection was done within short period while checking the physical condition of carcass to note the stages of decay. Six insect families of three orders were collected from the carcass killed by strangling namely the Muscidae (32\%), Sarcophagidae (16\%), Calliphoridae (16\%), Dermestidae (16\%), Chrysomelidae (4\%) and Cleridae (5\%). In the carcass killed by slaughtering method, the families obtained were Muscidae (50\%), Sarcophagidae (18\%) Calliphoridae (18\%), Dermestidae (9\%), Staphylindae (5\%). There was no significant difference $(P>0.05)$ in the succession pattern of the insects though more individuals were obtained in the strangled carcass $(55 \%)$ compared to the slaughtered carcass $(45 \%)$. This study shows that the succession pattern may have no significant or obvious influence on the decomposition of carcasses. Therefore there is need to probe further into other killing methods.
\end{abstract}

DOI: https://dx.doi.org/10.4314/jasem.v23i3.18

Copyright: Copyright (C) 2019 Ojianwuna et al. This is an open access article distributed under the Creative Commons Attribution License (CCL), which permits unrestricted use, distribution, and reproduction in any medium, provided the original work is properly cited.

Dates: Received: 17 November 2018; Revised: 19 January 2019; Accepted 22 January 2019

Keywords: Carcass; decomposition; forensic; strangled; slaughtered

The science of insects does not only involve the understanding of insect species and their biology, but it also encompasses the application in service to man (Al-Musawy et al., 2016). Insects are very important arthropods playing a number of roles, and are almost indispensable to the ecosystem. One of the many roles of insects is their involvement in decay and decomposition of carcasses. Understanding why and how is an area of applied entomology referred to as forensic entomology. Al-Musawy et al. (2016) described forensic entomology as the scientific study of the invasion and succession pattern of forensically important insects, predominantly in relation to their developmental stages found on carcasses during research or legal investigation. Forensic entomology may be used to detect drugs or poison in a system, determine the location of an incident and find out the presence and time a wound was inflicted (Amendt et al., 2007). Abajue et al. (2015) noted that forensic study is geared towards estimating the Post Mortem Interval (PMI) which is the time since the death of an individual and possibly finding out the circumstance that led to the death of that individual especially in homicides and suicidal circumstances. The use of insects recovered on the corpse or at the death scene may be useful in the determination of the cause of death. Insects associated with carcasses and their succession varies according to many factors, one of them being the geographic region which defines the habitat, vegetation, soil type or meteorological condition of a particular area. This could have an impact on the insect type and species present, as well as their seasonal availability (Mashaly and AlMekhlafi, 2016).

Forensic entomological investigators are often employed in the investigation of suspicious deaths as insects can provide vital information on when, where and how death occurred (Mashaly and Al-Mekhlafi, 2016). This, according to Anderson (2001), means that the distribution of species found on a corpse is indicative of its stage of decomposition and also time of death. A particular behavioural feature of forensically important insects is that they invade a dead body in a sequence or succession with different groups being attracted to different stages of decomposition. Therefore, it is important to understand the succession pattern on carcasses. 
The knowledge of the PMI can help in criminal investigation as well as homicides (Abajue et al., 2015) as it will enable law enforcement agencies and medical coroners in consolidating their findings especially when decay is at an advanced stage. The succession pattern of an insect can help to establish the effect of environmental factors on the carcass using the invasion as well as succession pattern and the developmental stages most especially the egg, larval noted. The use of non-humans e.g. pigs (Anderson, 2001; Abajue et al., 2015) and rabbits (Al-Musawy et al., 2016) are almost purely research-based and used as a model to study insect succession on carcasses in Nigeria and around the world, hence the PMI can also be estimated with these animals. However, it is noticeable that most of these studies are only aimed at identifying and recording the entomofauna of carcasses independent of further probing. What has largely been neglected is the application of killing methods. For instance a burnt or charred carcass might not be expected to decay in same way as a fresh carcass, or at least in the same time frame. This research is therefore, aimed at unraveling the forensically important insects species associated with Rattus norvegicus, thereby, establishing a relationship in the succession pattern of insects between the killing methods (strangled and slaughtered).

\section{MATERIALS AND METHODS}

Study Site: Abraka town is located in Ethiope East L.G.A in Delta State Nigeria along Latitude $5^{\circ} 47^{\prime} 24^{\prime \prime} \mathrm{N}$, Longitude $6^{\circ} 06^{\prime} 177^{\prime \prime E}$ and situated $29 \mathrm{~m}(95 \mathrm{ft})$ above sea level. The study area has a tropical wet and dry climate, with an extensive wet season with moderately constant temperatures (25 $30^{\circ} \mathrm{C}$ ) and average humidity of $70-80 \%$ throughout the course of the year. This study was conducted between May and June 2017 within Campus III of the Delta State University, Abraka. The area was weedy with tall shrubs. The site of the experiment was selected based on specific criteria, as it was isolated reducing human interference and scavenger disturbances.

Experimental Animal: Four (4) Albino Wistar rats, aged 12 weeks, two (2) of each sexes, weighing $272 \mathrm{~g}$ each were used for this experiment. The Albino Wistar rat is a strain of the laboratory rat species Rattus norvegicus. The rats were purchased from in-campus rodent rearers Dutch farms and used as models for the forensic experiment. The rats were killed on the first day of the experiment at exactly 8:15 am, by strangling (squeezing throat to cut off oxygen supply) and by slaughtering (slitting of the throat with a sterile blade), one method for a pair of different sex. The carcasses were secured from scavengers in a way that did not necessarily restrict access to the carcasses and also enabled insect collection (Al-Musawy et al., 2016). Directions on labels were placed around the area to restrict Human interference. The rats were kept outside 13 feet apart from each other to prevent clash of fauna. The carcasses were prevented from rain by ensuring, prior to the procedure, the presence of enough canopies which did not necessarily restrict sunlight and insects' carrion accessibility (Al-Musawy et al., 2016)

Sampling Procedure: Insects found on the carcasses were collected 24 hours after killing with forceps and aerial sweep net and placed in labeled vials some of which contained Ethyl acetate for preservation as proper documentation was written down of dates, stages of decomposition and type of specimen collected. Collection was done at 4 hours interval (8:20 am, 11: $20 \mathrm{am}, 3: 20 \mathrm{pm}$ and 7: $20 \mathrm{pm}$ ) so as not to disturb the carcass. Insects were collected from the carcasses for a period of 2 weeks. Insects found on the carcasses were collected daily during the fresh stage which lasted for 2 days and the bloated stage which lasted for 2 days as well. Although, the active stage of decomposition which lasted for 5 days, insect collection was done every other day. Soil around and underneath the carcass was examined for maggots, while observing the physical condition of the carcass to record the stages of decay. Time of collection and exact point of recovery was documented for different species during sampling. In the laboratory, each individual specimen was identified to their respective species level with the help of identification keys. (Centeno et aI., 2002; Bharti and Singh, 2003; AlMusawy et al., 2016)

Statistical Analysis: An independent-samples t-test was conducted to compare succession pattern in the stages of decay and the insects collected from both methods of killings. Results were considered significant at the significance level of $(P<0.05)$

\section{RESULTS AND DISCUSSION}

Strangled Carcass: Fresh stage: This stage lasted for 2 days. No foul odour or swelling was noticed, and no change in physical state. Species collected and identified during this stage include dipterans Musca domestica and Calliphora vicina (table 1).

Bloated stage: Swelling of abdomen noticed; no strong odour; fluid and exudes at orifices observed. This stage lasted for 2 days, ending when carcass deflated. Here, sarcophagids like the Chrysomya sp and Sarcophaga 
$s p$ emerged in addition to the other dipteran species identified (table 1).

Active decay stage: Full decomposition observed; flesh pierced by feeding insects; strong odour noticed; fluid and exudes seeping out from skin, eyes and mouth. This stage lasted 5 to 6 days as odour faded, with the disappearance of skin and flesh, revealing bones and dried tissue. Beetles like the Dermestes $s p$ and Paederus $s p$ were observed during this stage (table $1)$.

Table 1. Insect succession of the strangled carcass

\begin{tabular}{|c|c|c|c|c|}
\hline Days & Stage & Order & Family & Species \\
\hline $1-2$ & Fresh & Diptera & $\begin{array}{l}\text { Muscidae } \\
\text { Calliphoridae }\end{array}$ & $\begin{array}{l}\text { M.domestica } \\
\text { C.vicina }\end{array}$ \\
\hline $3-4$ & Bloated & Hymenoptera & $\begin{array}{l}\text { Muscidae } \\
\text { Calliphoridae } \\
\text { Sarcophagidae } \\
\text { Formicidae }\end{array}$ & $\begin{array}{l}\text { M.domestica } \\
\text { C.vicina } \\
\text { Sarcophaga sp. }\end{array}$ \\
\hline $5-10$ & Active & $\begin{array}{l}\text { Hymenoptera } \\
\text { Coleoptera }\end{array}$ & $\begin{array}{l}\text { Calliphoridae } \\
\text { Sarcophagidae } \\
\text { Formicidae } \\
\text { Dermestidae } \\
\text { Staphylinidae } \\
\end{array}$ & $\begin{array}{l}\text { C.vicina } \\
\text { Chrysomya sp. } \\
\text { Sarcophaga sp. } \\
\text { Dermestes sp. } \\
\text { Paederus sp. }\end{array}$ \\
\hline Days & Stage & Order & Family & Species \\
\hline $1-2$ & Fresh & Diptera & Muscidae & M.domestica \\
\hline $3-6$ & Bloated & $\begin{array}{l}\text { Diptera } \\
\text { Hymenoptera }\end{array}$ & $\begin{array}{l}\text { Sarcophagidae } \\
\text { Calliphoridae } \\
\text { Formicidae }\end{array}$ & $\begin{array}{l}\text { Sarcophaga sp. } \\
\text { Chrysomya sp. }\end{array}$ \\
\hline $7-13$ & Active & $\begin{array}{l}\text { Diptera } \\
\text { Coleoptera }\end{array}$ & $\begin{array}{l}\text { Sarcophagidae } \\
\text { Calliphoridae } \\
\text { Dermestidae } \\
\text { Cleridae } \\
\text { Chrysomelidae } \\
\text { Formicidae } \\
\end{array}$ & $\begin{array}{l}\text { Sarcophaga sp. } \\
\text { Chrysomya sp. } \\
\text { Dermestes sp. }\end{array}$ \\
\hline
\end{tabular}

Slaughtered Carcasses: Fresh stage: This stage lasted for 2 days, again without noticeable change in physical state. No strong odour was noticed. Only the Musca domestica was noticed during fresh decay (table 2).

Bloated stage: This stage lasted about four days, with decay noticed as well as insect succession before deflation. Chrysomya $s p$ as well as Sarcophaga $s p$ were identified (table 2).

Active decay stage: This followed after deflation with the appearance of dipterous maggots. Very strong odour and skin disintegration was noticed. This stage lasted for about a week. Chrysomelid, dermestid and clerid beetles were observed in addition to Formicid or fire ants which were again present during all three decay stages. The study revealed the occurrence of insects of the order Diptera, Hymenoptera, Coleoptera occurring at different stages of decomposition (Fig. 1).

Musca domestica the only observed species of the family Muscidae, and the most predominant species as observed in all 3 especially during the early decomposition stage. Calliphorids (blowflies) were observed in all stages of decomposition of the strangled carcass, but only observed in the active stage of the slaughtered carcass. This correlate with the findings of Centeno et al. (2002), Bharti and Singh (2003), Ekanem and Dike (2010) and Al-Musawu et

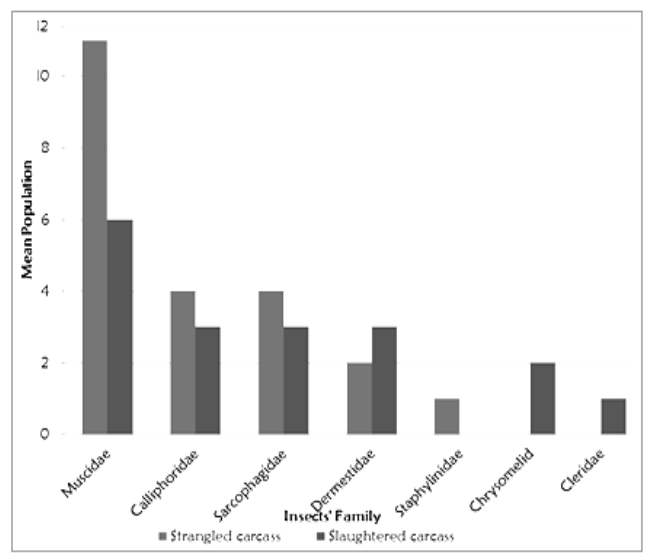

Fig. 1. Mean population of insects' family recovered on both carcasses

al. (2016). Savage (2002) stated that Necrophagous Diptera help in nutrient cycling in terrestrial ecosystems which in turn accelerates the disintegration of animal tissue thereby facilitating the action of microorganisms. The point that they are always 
present in decaying carcasses highlights the purpose why they are used commonly in the investigation of suspicious death.

In the strangled carcasses which showed more entomofauna, the dipterous maggots that appeared during the active stage are of the muscids and calliphorids observed earlier, Dipterans are known to lay eggs on decomposing flesh, and these eggs underwent development till the insects reached adult stage. The succession of same families of Diptera at the onset of decay through to the bloated and active stages both in the strangled and slaughtered carcasses, shows the same succession pattern relative to manner of death.

However, decomposition was observed to be a bit faster in the strangled carcasses. This is in spite of all carcasses been exposed to relatively equal amount of sunlight, even though meagre due to the presence of canopy. It is important to note that the fresh stages took 2 days before the swelling of the abdomen was noticed. The bloated stages of the strangled and slaughtered carcasses showed differences. In the strangled carcasses, the bloated stage took about 2 days and during this time, there was visible disintegration as well as simple entomofauna. Exudes were observed at the orifices, with little odour noticed. In contrast, the slaughtered carcasses showed no disintegration until at least the active stage which still took longer than in that of the strangled carcasses.

To explain the reason for this, we must assume that there was indeed a difference in exposure to sunlight nonetheless as this is the most common environmental factor that can significantly alter decomposition rate (Centeno et al., 2002; Cruz et al., 2013; Al-Musawy et al., 2016). Only the $M$. domestica was observed during the fresh stage in the slaughtered carcasses. This is difficult to explain as one would expect more necrophagous species, particularly the calliphorids, due to early tissue exposure. The presence of these species confirms their importance to forensic investigations, having also been found in human cadavers (Cruz et al., 2013) and regarded as the most common.

Dipterous maggots featured during the active stages of decomposition. A few however were observed during the bloated stage in the strangled carcasses. The appearance of few maggots towards the end of the bloated stage shows the function of faster rate of decomposition, it was observed that, maggots which are dipteran larvae follow the invasion of egg-laying dipteran and quicker appearance must have been as a result of quicker invasion of the muscids and calliphorids, thus their appearance during the bloated stage, rather than, more at the active stage.

Dead animals begin to deteriorate minutes after death due to physiological changes which have come to a halt, thus leading to putrefaction. Insects like flies, according to (Abajue et al., 2013; Abajue et al., 2015) are evidence of this deterioration as they are the first to detect this change and arrive on the carrion. It is possible therefore that fewer Diptera species (one in fact) observed during the fresh stage of decay in the slaughtered carcass, resulted in slower rate of decomposition, since, according to the aforementioned authors, Diptera lay eggs on the carrion which hatch quickly, developing into larvae that feed on the tissues, hence faster decomposition.

As suggested by (Kyerermaten et al., 2013), carrion insects are decomposition stage dependent. Ants (Formicidae), however, were noticed around each carcass from fresh to active decay stage and in no particular pattern. Ants can be regarded as predators and omnivores. Worthy of note, according to Ekanem and Dike (2010), Formicidae possesses strong mandibles that enables them to take off pieces of decomposing carcasses as well as prey on dipterous eggs and larvae and any other easily reached arthropods on the carcasses their incursion specifically as they come in colonies, may have affected the carcass decomposition level, either by predating on immature stages of dipterous flies or by the deduction of portion of the carcasses. These Hymenopterans collected during the experiment did not necessarily breed on the carcasses or affect the decay. Hence, they are not, in this context, the most forensically important insects (Bharti and Singh, 2003; Ekanem and Dike, 2010).

Beetles (Coleoptera) like the Dermestes sp. and Paederus $s p$. observed on the carcasses exposed the skeletons of these carcasses; similar findings with that of (Abajue et al., 2013). The different beetle families were all collected during the active stage. Beetles, according to (Abajue et al., 2015) are forensically important insects and mostly appear during the late stages of decay. The beetle families observed on the carcasses differed, the Dermestids were present in both methods of killings while the Clerids and Chrysomelids occurred only on the slaughtered carcasses and the Staphylinid also appeared only in the strangled carcass. According to Gill (2005), beetles' activity was in actual fact associated with the advanced stages of degradation process causing the drying out of semi liquid soft tissues. 
Generally, similar succession pattern was observed in both strangled and slaughtered carcasses, with similar entomofauna. It is therefore understood that Coleoptera and Diptera are the most common forensically important insect orders and findings of this study confirm that. The only difference in Diptera succession is that which is relative to decay stage, only the muscids were observed during the fresh stage in the slaughtered carcasses as opposed to the presence of calliphorids on the strangled carcasses. However this may be due to calliphorids characteristically exhibiting habitat preference as suggested by Al-Musawy et al.(2016) and Mashaly and Al-Mekhlafi (2016).

As for the physical state, the same pattern of disintegration was observed. The main debate here is the difference in time frame and decay intervals as recorded and illustrated in the tables. The bloated stages differed in timeframe ( 2 and 3 days). The slaughtered carcasses underwent 13 days of recorded decomposition in 3 states as opposed to 10 days for the strangled carcasses. Grounded on our discoveries, one can assume that there were more individuals in each family and hence faster decay rate in the strangled carcasses. Rate of decay is indeed associated with insect invasion and succession but perhaps not the type of insect fauna. All carcasses showed same succession pattern despite the killing methods differing, if of course we isolate environmental factors and the rate of decay.

Conclusion: The manner of death is an area commonly considered in investigation of suspicious deaths. The findings of this study may show that the manner of death has no obvious effect on the insect succession pattern on the carcass. Perhaps more experiments using other guinea pigs could be attempted in this area to unravel useful information beyond the level of preliminary investigation. This could help simplify more complicated death cases in the future.

\section{REFERENCES}

Abajue, MC; Akunne, CE; Ewuim, SC (2013). Insects associated with decomposing pig carrions in Okija, Anambra State, Nigeria. The Bioscientist. 1(1): 54-59

Abajue, M; Akunne CE; Ewuim, SC (2015). Preliminary checklist of beetles associated with pig carrion decomposition in Okija, Anambra state, Nigeria. Anim. Res. Inter. 12(2):2166-2170

Al Musawy, HR; Alboshabaa, H; Hameed, S (2016). The taxonomic composition of the forensically important insects in the rabbit carcasses during two seasons in An-Najaf province, Iraq. World $J$. Pharma. Res. 5(4):2068-2077

Amendt, J; Campobasso, CP; Gaudry, E; Reiter, C; LeBlanc, HN; Hall, MJ (2007). Best practice in forensic entomology. Int. J. Legal Med. 121(2): 90-104

Anderson, GS (2001). Insects' succession on carrion and its relationship to determining time of death. Forensic Entomology: The utility of Arthropods in legal investigations. Anderson GS, Bryrd JH, Castner JL (Eds). CRC Press, Boca Raton, Florida. Page 143-175

Bharti, M; Singh, D (2003). Insect faunal succession on decaying rabbit carcasses in Punjab, India. $J$. Forensic Sci. 48(5).

Centeno, N; Maldonado, M; Oliva, A (2002). Seasonal patterns of arthropods occurring on sheltered and unsheltered pig carcasses in Buenos Aires province (Argentina). Forensic Sci. Inter. 126;6370.

Cruz, T; Salgado, R; Thyssen, P; Vasconelos, S (2013). Dipterans associated with a decomposing animal carcass in a rainforest fragment in Brazil. J. Insect Sci. 3(145):1-11.

Ekanem, MS; Dike, MC (2010). Arthropods succession on pig carcasses in Southeastern Nigeria. Papeis Avulsos de Zoologia. 50(35):2763.

Gill, GJ (2005). Decomposition and arthropod succession on above ground pig carrion in rural Manitoba. Canadian Police Research Centre Technical report number:1-180.

Kyerematen, RA; Boateng, BA; Haruna, M; Eziah, V (2013). Decomposition and Insect Succession pattern of exposed domestic Pig (Sus scrofa) carrion. J. Agric. Biol. Sci. 8(11):756-765.

Mashaly A; Al-Mekhlafi, F (2016). Differential Diptera succession patterns on decomposed rabbit carcasses in three different habitats. J. Medical Entomology. 1-6

Savage, J (2002). Exploring the diversity of flies (Diptera) Cleaning up the world. Biodiv. 3:12-15. 